\title{
Fichte: Kantian or Spinozian? Three Interpretations of the Absolute I
}

\author{
Alexandre Guilherme \\ Department of Philosophy \\ University of Durham \\ 50-51 Old Elvet \\ Durham, Co. Durham \\ DH1 $3 \mathrm{HN}$ \\ United Kingdom \\ Email: alexandre.guilherme@durham.ac.uk
}

\begin{abstract}
Fichte is the first great Post-Kantian Idealist and his debt to Spinozism has been acknowledged by virtually all of his commentators. However, the extent of Spinoza's influence on Fichte has not been spelled out in much detail. In response to this I propose to do two things. Firstly, I propose to provide a typology of interpretations of Fichte's Absolute I, as some commentators seem to get entangled in these different interpretations, which can be very confusing to their readership. Secondly, I wish to demonstrate that the Fichtean system is better understood in the light of its Spinozist influences.
\end{abstract}

\section{Background to Fichte's Project}

Towards the end of the 18th century the Enlightenment movement faced a major crisis. This crisis was brought about because when one of the movement's central tenets, namely rational criticism, was radicalised (and it had to be radicalised because to put a limit to it would be arbitrary). The radicalisation of rational criticism lead to scepticism for when one examined one's own beliefs one found that the evidence for these same beliefs could go either way in confirming or refuting these beliefs.

Kant attempted to solve the crisis with the publication of his Critique of Pure Reason, the central question of which is: How is knowledge possible at all? Needless to say that Kant was not entirely successful in dealing with the crisis, which triggered a series of responses and further developments by his contemporaries. It was generally understood that Kant had failed in his attempt because his critical philosophy was plagued by a number of dichotomies, such as appearances and thing-in-itself, sensibility and understanding, and as such Kant had provided a system which was not entirely unified. This is an important point which should not be overlooked as at that time philosophers understood that philosophical systems had to be unified and systematic. Due to this issue many of those who attempted to succeed where Kant had failed sought in Spinoza for inspiration in their search of an unified system for Spinozism epitomised the system that is both systematic and unified. Fichte was one of those who sought in Spinoza the answers to the problems faced by the critical philosophy of Kant as it is acknowledged by virtually all of his commentators. 
In writing the Wissenschaftslehre project Fichte aimed at answering the same basic question that Kant unsuccessfully proposed to answer in the First Critique (i.e. How is knowledge possible at all?) and in this sense Fichte's project is a development of the Kantian project; however, he attempted to do so in a more unified way. As such, it could be said that Fichte tried to merge the critical philosophy of Kant with the systematicity of Spinoza.

When Fichte attempts to answer the question 'How is knowledge possible at all?', Fichte aims at providing the foundation of all experience, a first principle which grounds all experience, and this first principle is the 'Absolute I'. Fichte was a foundationalist (just as all his predecessors and contemporaries) and as such he understood that the sceptic threat could only be overcome by a sound foundation to all knowledge. But the concept of the 'Absolute I' is more than a mere epistemological foundation; it is rather the cornerstone, it is the first principle of his whole Wissenschaftslehre project. That is, Fichte (and his contemporaries) understood that philosophy ought to be systematic, and as such he attempted to derive his system from this first principle. This means that Philosophy for Fichte was a science just as Physics and Biology are, and as such it required a first principle which could serve as the foundation of all philosophical enquiry.

\section{Fichte: Kantian or Spinozian?}

JG Fichte (1762-1814) is the first great Post-Kantian Idealist. His Kantianism has been acknowledged since the beginnings of his career by his commentators, and rightly so. Fichte (1993:357), himself, acknowledges in a letter dated August-September 1790 to his friend Weisshuhn that:

...I have been living in a new world ever since reading the Critique of Pure Reason. Propositions which I thought could never be overturned have been overturned for me. Things have been proven to me which I thought could never be proven for example, the concept of absolute freedom, the concept of duty, etc. and I feel all the happier for it. It is unbelievable how much respect for mankind and how much strength this system gives us.

This passage clearly shows how fascinated he was with Kant's philosophy, and thus the question here is: Why was Fichte so taken by Kant's writings? To answer this question I must refer to events in Fichte's early academic life. Green (1978:1-2) notes that Fichte:

like both Schelling and Hegel, the other leading Idealist philosophers,...began as a student of theology, though his subsequent career earned him a reputation primarily as a philosopher. He was eighteen years old when he enrolled as a theological student at the University of Jena in 1780 . Neither there nor in his subsequent studies at Wittenberg and Leipzig did he devote himself to a study of Kant's philosophy, the crowning works of which were coming into print during these years. Rather, he seems to have become convinced of the truth of determinism, especially as articulated in Spinoza's Ethics. The struggle to free himself from a deterministic view of the world began during his student years and remained a major motive throughout his subsequent life and writings...

Within the context of his early academic life, it becomes clear that when Fichte says in his letter to Weisshuhn that propositions which he thought could never been overturned had been overturned for him, he is clearly making reference to his early faith in 
Spinoza's philosophy, especially its determinism, and how it had been overturned by Kant's philosophy. Within the Kantian system both the natural laws that govern the physical world and the freedom of the will are secured by the distinction between practical and pure reason, as well as by the distinction of phenomenal and noumenal realms. Thus, it can be said that the young Fichte was a devotee of Spinozism and determinism, despite being deeply concerned by the moral implications of such views. His conversion to Kantianism came about only later after reading Kant's Critiques. Fichte understood that Kant's critical philosophy pointed in the right direction as it attempted to safeguard both the natural laws that govern the physical world and freewill: each had a place within a specific realm. Certainly, Fichte remained concerned with the lack of systematicity in Kant's philosophy and troubled by its numerous dichotomies.

Fichte's early faith in Spinozism was also noted by Breazeale (1993:3-4). I quote:

Little is known concerning Fichte's philosophical orientation during these early years. He appears to have subscribed to the Leibnizian-Wolffian system, which he interpreted in a strictly deterministic manner. The surviving evidence shows how, under the influence of this interpretation, the young Fichte reluctantly abandoned his own belief in free will and became a defender of metaphysical fatalism. Although such an interpretation was rejected by Leibniz and Wolff themselves (who insisted upon the compatibility between 'free will' and 'determinism'), it was nevertheless widespread in the late eighteenth century and was often (and derisively) identified with 'Spinozism'. The debate over the issue of 'Spinozism' and its alleged pantheistic consequences was one of the most important intellectual concerns of the era and reached its peak in the early 1780s (with the pantheism controversy)...In the debate the young Fichte appears to have been firmly on the side of the metaphysical determinists.

Further corroborating my claim about Fichte's early Spinozism is the following passage from a letter dated $2^{\text {nd }}$ July 1795 from Fichte to Reinhold where Fichte, himself, acknowledges his Spinozism. I quote Fichte (1993:401):

Judging by what I have read of it, Schelling's entire essay is a commentary on my writings. But he has grasped the matter splendidly, and several people who did not understand me have found his essay very clear. Why he does not say so [i.e. that his essay is a commentary on the Wissenschaftslehre] I do not quite understand. He will not wish to deny this, nor could he do so...I am glad that he has appeared. I am particularly fond of his references to Spinoza, on the basis of whose system mine can most properly be explained.

Fichte had several avenues for learning about Spinoza and Spinozism for as Wright (2003:161) states:

Fichte had several avenues for learning about Spinoza. First he possessed the 1677 edition of Spinoza's Opera Posthuma. Beyond that, however deeply he may actually have studied Spinoza's texts, Fichte certainly also knew of his ideas through Jacobi's writings, especially Uber die Lehre des Spinoza in Briefen an Herr Moses Mendelssohn.

And adding to this is the fact that Fichte must also have been familiar with Pierre Bayle's commentary on Spinoza, in his Dictionnaire Critique et Historique (An Histor- 
ical and Critical Dictionary in English), since this was part of the canon of most European Universities. Bayle's Dictionnaire was first published in 1695 and it was translated into German in 1741 and therefore Fichte could have had come into contact with Bayle's work as early as 1780 when studying at Jena. The Dictionnaire made of Bayle an 'opinion-maker' and his entry on Spinoza became the classic refutation of Spinoza's ideas during the $17^{\text {th }}$ and $18^{\text {th }}$ century, which accounts for much of the misunderstandings and misinterpretations surrounding Spinozism at the time. Bayle's interpretation of Spinozism is now regarded as seriously mistaken and contemporary commentators tend not to pay much attention to it.

Thus far I have established that Fichte, at least in his early academic life, was a Spinozist, as acknowledged by commentators and Fichte himself; and I have also established that Fichte was able to learn about Spinoza and Spinozism through various avenues and sources. However, I want to press on with the stronger claim that Fichte never truly gave up Spinozism. That is to say, I understand that Fichte retained many Spinozist themes throughout his life, although, perhaps, in a less pure fashion after his encounter with Kantianism. Support for my claim is the letter quoted above of Fichte to Reinhold, since he clearly refers to his Wissenschaftslehre project (this project encompasses various works which were written during Fichte's mature academic years, and written after his encounter with Kantian philosophy) and where he pays tribute to Spinoza as the chief and most consistent dogmatic (to be read materialistic) philosopher. I quote from Fichte's Wissenschaftslehre project:

So far as dogmatism can be consistent, Spinozism is its most logical outcome...(Fichte 1970:117)

I believe that there is enough evidence in Fichte's correspondence and writings as well as acknowledgement by commentators to support my thesis that Fichte was a Kantian insofar as he subscribed to Kant's critical philosophy as well as being a Spinozist insofar as he referred back to Spinoza's philosophy in trying to solve the problems of Kant's philosophy.

\section{Absolute I: Three Interpretations}

In writing the Wissenschaftslehre project Fichte aimed at answering the same basic questions that Kant unsuccessfully proposed to answer with the First Critique. Fichte aimed to answer: how is knowledge possible at all? In answering this question Fichte searched for two things: $i$. the foundation of all experience and ii. a first principle which would ground his philosophical system. The concept of the Absolute I is Fichte's common answer to both issues. Fichte's concept of the Absolute I is the foundation of all experience as well as being cornerstone of his Wissenschaftslehre project. Fichte refers to the concept of the Absolute I in quite a few passages of his writings. One of such passages is the following:

The Absolute Ego of the first principle is not something (it has no predicate and cannot have any); it is absolutely what it is, and this cannot be further explained. But now, by means of this concept, consciousness contains the whole of reality; and to the not-self is allotted that part of it which does not attach to the self, and vice-versa. Both are something; the not-self is what the self is not, and vice-versa. As opposed to the Absolute-self...the not-self is absolutely nothing; as opposed to the limitable self is a negative quantity...(Fichte 1970:109-110). 
The obscurity of Fichte's language does not help his readers to make a complete sense of what he means by this concept. In fact, Henrich (1982:23-24) notes this point when he says:

Fichte's language steadfastly resists the implications of this model and therefore has to make use of many metaphors that are very difficult to understand.... This explains why Fichte's task was so difficult and why he never succeeded in elaborating his theory with complete clarity, even though this was his goal. Consequently, rather than communicating his discovery, he hid it in texts that are among the most opaque and refractory in the entire tradition. The interpreter has to expend the same effort Fichte applied to the issue itself if he wants to free this discovery from the thicket of incomplete manuscripts.

Despite the obscurity of this concept and 'for all the problems in admitting the existence of an absolute ego in his (Fichte) system, the fact still remains that Fichte writes of an absolute ego. The problem is then how to interpret such language. What does such language mean? And does it commit Fichte to the existence of the Absolute Ego?' as noted by Beiser (2002:284). And as Henrich says 'the interpreter has to expend much effort" in trying to make sense of Fichte's Absolute I. My investigations on this concept have yield the surprising finding that there are three main interpretations of this concept, namely, what I call "the classical interpretation' of Schelling and Hegel, 'the strong idealist interpretation' of Jacobi and Novalis, and 'the modern interpretation' of commentators such as Breazeale, Pippin, Zöller, Neuhouser and Henrich. I shall now provide the reader with an outline of each of these interpretations and demonstrate the connection with Spinozism which each of these interpretations have.

According to the classical reading of Schelling and Hegel, the main thesis of Fichte's project could be outlined as: there is an entity, an Absolute I, that somehow continuously creates the whole of reality, including Nature as a not-I and individual consciousnesses as relative "I"s, as noted by Bowie (2003), Dusing (1999), and Copleston (1946). It is perhaps interesting to quote the following passage by Copleston (1946:47) who summarises the classical reading well:

In Fichte's system, therefore, Kant's Transcendental Ego blossomed out as the Absolute Ego, the ultimate source of finite subjects and objects...

Support for this classical interpretation can be found in Schelling's writings, especially in his work On the I as a Principle of Philosophy, where Schelling (1980:104) describes the Absolute I of Fichte's Wissenschaftslehre project as:

...the Absolute I is neither a merely formal principle, nor an idea, nor an object, but pure I determined by intellectual intuition as absolute reality [my italics]

And Schelling (1980:105):

...one speaks commonly of the existence of God, as if God could really exist, that is, could be posited conditionally and empirically (that, of course, is what is desired by most people and, as it seems, even by many philosophers of all times and factions). Anyone who can say that the Absolute I exists knows nothing about it.

In the first passage Schelling says that the concept of Absolute I is to be understood as 'absolute reality', and this is to be understood as the very source of all reality, as the underlying principle that holds everything together - the Absolute I is the point of ori- 
gin of all reality. And in the second passage Schelling is saying that just as the existence of God could not be asserted conditionally and empirically, so it is with the Absolute I. That is, to condition or empirically assert an absolute is to turn the absolute into a relative. The absolute cannot be conditioned by anything or empirically asserted by its own nature. Only relatives are conditioned by other relatives and only relatives are empirically asserted. Schelling seems to be asserting that since the concept of God and the concept of the Absolute I share some particular characteristics, i.e. their absolute-ness and their unknowability, then it seems that the concept of Absolute I could be equated with the concept of God.

The following passage from Hegel's The Difference Between Fichte's and Schelling's System of Philosophy also corroborates the interpretation that the Absolute I is God. I quote Hegel (1977:159):

After all, as Fichte says somewhere (see Fichte, Werke I, 253), his own system would only be formally correct for God's self-consciousness - a consciousness in which everything would be posited through the Ego's being posited.

It is worth here to refer to the letter dated $2^{\text {nd }}$ of July 1795 of Fichte to Reinhold where he acknowledges that Schelling's interpretation was correct. I quote Fichte (1993:401):

Judging by what I have read of it, Schelling's entire essay is a commentary on my writings. But he has grasped the matter splendidly, and several people who did not understand me have found his essay very clear. Why he does not say so [i.e. that his essay is a commentary on the Wissenschaftslehre project] I do not quite understand. He will not wish to deny this, nor could he do so...I am glad that he has appeared. I am particularly fond of his references to Spinoza, on the basis of whose system mine can most properly be explained.

And in a letter dated $30^{\text {th }}$ August 1795 to Jacobi, Fichte (1993:411) explicitly says that:

... the pure I (i.e. the Absolute I) is posited outside ourselves and is called God...

This statement clearly corroborates the classical reading that the 'Absolute I' is 'God'. In the classical reading, Fichte's Absolute I becomes virtually identical to the classical interpretation of Spinoza's substance, such as found in Pierre Bayle's Dictionnaire Historique et Critique, which, as I mentioned above, was standard reading in most European Universities, and as such Fichte must have been familiar with it. By following such interpretations of Spinoza's substance it could be said that both Fichte's Absolute I and Spinoza's substance are the primary principle out of which their philosophical systems are derived. Not only that, both the Absolute I and the substance continuously creates reality, i.e. these entities are the source or the point of origin of, reality; and both are equated to God as an immanent entity. As an immanent entity, God is within everything in reality; God is present in all that encompasses reality; God underlies and joins the whole of reality together.

I can identify a problem for Fichte if the classical reading is accurate. He must spell out what sort of relation the Absolute I has with all the relative "I"s and with nature as a not-I. Unfortunately he does not explicitly say so. The problem of the right kind of relation between the substance and its modes is well known and it has plagued 
Spinozism since the late 17th century. I believe, if the classical reading is correct, that this problem is transferable to the relation that the Absolute I bears with the relative "I"s and nature as a not-I. ${ }^{1}$ I, however, understand that if one is to make sense of Fichte's views here, and by what Schelling says in his interpretation, that the relation between the Absolute I and the relative "I"s and nature as a not-I is to be interpreted as a causal relation - i.e. the Absolute I continuously creates, i.e. causes to be, the relative "I"s and nature as a not-I.

The classical reading ties in well with one of the Kantian thesis in the Critique of Practical Reason. In his Second Critique Kant asserted that morality requires the postulation of a God, a God who is the guarantor that human action can be successfully enacted in the world. Kant, however, does not spell out how God, as a transcendent being, does this and this presents a problem. Fichte's first published work, the Attempt at a Critique of All Revelation, followed Kant's argument very closely and did not spell out how God acts as the guarantor either. Fichte must had become aware of this problem, because, if the classical reading is correct then Fichte is transforming the transcendent God into an immanent entity. This move seems to solve the problem as an immanent God, a God that continuously creates the whole of reality, "I"s and not-"I"s, is a God that can guarantee the congruency of all things, including subjective agency over objectivity. Bowie (2003:72) corroborates this:

The difficulty always lies in how two sides can be connected if they are supposed to be of a different order from each other. If nature is merely objective and deterministic, then its relationship to subjectivity becomes problematic. Fichte's solution to this problem was the idea of an absolute I which includes both individual consciousnesses and nature within it, as relative I and not-I...

This classical reading understands that if the subjective can successfully enact in the objective, then, this implies that the subjective can also successfully experience the objective. It is through this experiencing of the objective that we, as subjective beings, are able to gain knowledge of reality. It is this very implication of the reading of the Absolute I as an immanent God that provide us with Fichte's answer to the Enlightenment crisis and to the threat of scepticism. As I mentioned before, for the 18th century philosopher the only acceptable solution to this problem was to provide a proper foundation to one's beliefs so that one's beliefs are always properly grounded. Fichte's answer to the problem is that the Absolute I, the immanent God, continuously creates the whole of reality, i.e. nature as a not-I and the relative "I"s, and as such it acts as a connection that enables the relative "I"s to experience and gain knowledge of the not-I. The Absolute I is the foundation of our experiencing of reality.

I note, however, that the textual evidence for this classical reading is scattered and it cannot be conclusive. In Fichte's writings one also finds evidence supporting the strong idealist and the modern reading of Fichte's concept of "Absolute I".

The strong idealist reading was put forward by Jacobi and Novalis, and it has been noted by Di Giovanni (1994), Bowman (2002), Zöller (1998) and Henrich (1982). Ac-

1 NB. There are three main readings regarding the substance-mode relation. Pierre Bayle, in his Dictionnaire Critique et Historique reads Spinoza as a Cartesian and the relation between the substance and its modes as a relation analogous to the subject-predicate relation. HA Wolfson, in his The Philosophy of Spinoza, reads Spinoza as an Aristotelian and the relation as a genus-species relation. Edwin Curley, in his Spinoza's Metaphysics, reads Spinoza in the light of modern physics and the relation as a causal relation (cf. Curley, E., (1969), Spinoza's Metaphysics, Cambridge, MA: Harvard University Press; Wolfson, HA., (1948), The Philosophy of Spinoza, Cambridge, MA: Harvard University Press. 
cording to this reading the concept of the Absolute I plays the same role, or it has the same function, in Fichte's project as the concept of substance plays in Spinoza's metaphysical system. That is, the concept of the Absolute I is to be equated to the concept of substance only insofar as these concepts are the cornerstones of these philosopher's projects, but this is not to say that Fichte's concept of the Absolute I is to be equated with Spinoza's concept of substance insofar as this concept is God or Nature. Di Giovanni (1994:110-111) explains this well when he says:

Fichte had indeed chosen to give the name of "I" to his first principle and had clothed his account in the language of the "I". But this choice had meaning only programmatically, i.e. only inasmuch as, in terms of the assumed principle, it was possible to explain the possibility of genuine "selves". On Fichte's own admission, any such self would require individuation and hence historical determination. The supposed original "I", however, was ex hypothesi an unlimited act, a sheer Agilitat that in itself defied all determination...There was nothing to distinguish it per se from Spinoza's substance, in other words, except perhaps, as mentioned, the systematic work that it performed.

According to this strong idealist reading, Fichte's main thesis in the project is to be understood as the following: the concept of the Absolute I is the primordial principle and it is to be understood as a metaphysical expression of the individual and empirical I; it is sheer activity and spontaneity; it is the basis of consciousness. Note here that the Absolute I is not a mystical entity, it is not a God or Nature, it is merely the foundation for consciousness. The Absolute I is the very activity and spontaneity of rationality that gives rise to the I as an individual and empirical self - i.e. the Joes and Toms of reality. The individual and empirical self will, in turn, gives rise and oppose itself to that which is not-itself, a not-I - i.e. reality. Knowledge requires this kind of interaction, the interaction between a self and a not-self, since knowledge requires a subject-object relation. Thus, according to this reading the Absolute I is not God, as the classical reading interprets, but the foundation of rationality.

Interestingly, this reading also ties in well with the wider philosophical picture of the time. As I asserted previously, the enlightenment faced a crisis and was threatened by scepticism over the issue whether knowledge was possible at all. Kant tried to reaffirm the possibility of knowledge in his First Critique where he addressed the question: What can I know? Kant, however, had left too many issues unanswered and a system based on dichotomies. This strong idealist reading seems to fit this scenario well, as it seeks to establish a proper foundation for consciousness, the Absolute I, and thus serving as a first principle for a system that was properly unified and that solved those inconsistencies of the Kantian system. The foundation here is the Absolute I as rationality's activity and spontaneity that enables human beings to experience and gain knowledge of reality.

This interpretation of Fichte's Absolute I faces some criticisms. For Jacobi, who was a fierce critic of the Enlightenment's reliance on reason, such a unifying principle, the absolute principle, is the concept of God. And God has to be taken in faith and not in knowledge. Jacobi understands that the mere fact that we can affirm some knowledge about Fichte's Absolute I (i.e. that it posits itself as an individual I and that it then gives rise and opposes itself to a not-I, and that it bends the not-I to its will) renders this very entity not absolute but relative. That is, if Fichte's Absolute I is in fact an ab- 
solute principle, then we would have no knowledge of it - this is Jacobi's first problem with Fichte's system. Bowie (1993:21) corroborates this when he says:

Jacobi uses this notion of the inarticulable ground (i.e. of being in relation to anything else) to suggest that the only possible course for philosophy is to realise that it must transcend itself into revelation and belief in a personal God who is this Absolute. He thereby separates philosophy from theology, which becomes the realm of what cannot be explained but only revealed.

And Millan-Zaibert (2000:145) explains Jacobi's position concisely well when she says that for Jacobi:

...knowledge does not begin with a first principle which can be demonstrated, but with an absolute first principle that we must accept by an act of faith...

Jacobi's position is that the proper foundation to any knowledge, the first principle, cannot be demonstrated but only taken by faith. As such Fichte's Absolute I cannot be the foundation of knowledge; rather, for Jacobi, God is. Whether or not Jacobi's reading is fair to the letter of Fichte's philosophy is not at stake here - in fact, there is much textual evidence that does not support Jacobi's reading as I will demonstrate below when I deal with the modern reading of Fichte's philosophy. It is noteworthy, however, that Jacobi's reading was very influential and it later helped to shape Schelling's philosophy. It helped shape Schelling's philosophy because in the light of Jacobi's criticism Schelling, who at first was very sympathetic to Fichte's views, started to doubt that Fichte had really found the absolute principle, and this doubt prompt Schelling to enquire further into the nature of the absolute.

This situation led Jacobi to openly criticise Fichte's position in a letter. He claimed that Fichte's position was nothing more than an inverted Spinozism. That is, the concept of the Absolute I played the same role in Fichte's system as the concept of substance played in Spinoza's; however, whilst in Spinoza's system, according to Jacobi's reading (and the reading of most commentators of the time), starts and finishes in materialism, Fichte's system starts and finishes in thought. I quote from the letter:

Little was lacking for this transfiguration of materialism into idealism to have already been realized through Spinoza. His substance, which underlies extended and thinking being, equally and inseparably binds them together; it is nothing but the invisible identity of object and subject (demonstrable only through inferences) upon which the system of the new philosophy is grounded, i.e. the system of the autonomous philosophy of intelligence. Strange, that the thought never occurred to Spinoza of inverting his philosophical cube; of making the upper side, the side of thought which he called objective, into the lower, which he called the subjective or formal; and then of investigating whether his cube still remained the same thing; still for him the one and only true philosophical shape of reality. Everything would have transformed itself without fail under his hands at the experiment. The cube that had hitherto been "substance" for him - the one matter of two entirely different beings - would have disappeared before his eyes, and in exchange a pure flame would have flared up, burning all by itself, with no need of place or material to nourish it: Transcendental Idealism! (Jacobi 1994:502)

Jacobi's point here was well explained by Zöller (1998:21): 
For Jacobi, the transcendental idealism introduced by Kant and radicalized by Fichte dissolves reality into a mere figment of the mind. Rather than combating skepticism, Fichte's Wissenschaftslehre is seen as supporting doubt in everyday reality by replacing the realist worldview of ordinary consciousness with the idealist production of a world that is nothing but appearances and hence appearances of nothing.

Novalis (2003:166) noted the same complaint regarding the dangerous implications of Fichte's system, as he interpreted it. I quote:

When one speaks philosophically of that which is to come, for example, of the annihilation of the not-I, then one guards against the illusion that there would come a point in time where this would take place...In every moment that we freely act there is such a triumph of the infinite I over the finite one; for this moment the not-I is really annihilated.

Jacobi's second complaint about Fichte's system follows on from the points stated above. That is, Jacobi understands that the Fichtean system does not combat scepticism, rather it supports it. Jacobi's point is that if the basis of our knowledge is the Absolute I as sheer activity of the mind, an activity that gives raise to the empirical I and the not-I, then the material world is made redundant. In fact, one may take this to an extreme and say that since the Absolute I gives rise to my individual I and to the not-my-individual-I then I have no need of the material world, or for that matter, I have no need for other "I"s - I end up as an absolute solipsist.

Agotnes and Moven (2001:211-212) note that Schelgel took this criticism of Fichte's philosophy even further than Jacobi. Schegel understands that the fact that Fichte's doctrine ends up in absolute solipsism has a related implication. Schegel understands that since the individual ends up on his own, this causes the individual to be unable to fulfil his dannelse or the formation of the individual project, i.e. the formation of his character and the pursuing of his plans for himself. This is so because the individual requires the interaction with reality, the individual requires to bend out into the world, the individual requires to reach out for reality, and then back upon himself, back into his own reflexions, if he is to be able to complete the formation of his individual project. And according to the strong idealist reading this interaction with reality becomes an impossibility.

Recently, both the classical and the strong idealist readings have been discredited and have been, by and large, replaced by a modern reading after the works of commentators such as Breazeale (1993), Pippin (2000), Zöller (1998), Neuhouser (1990), Henrich $(1982 ; 2003)$ and Beiser (2002). I understand that this modern reading is a variation of Jacobi's reading. According to this reading the Absolute I is the activity and spontaneity of the mind that enables the individual I to arise. This individual I in turn meets with a not-I, with reality, so that a subject-object relation is established and thus providing the foundations for knowledge. Note here that according to this reading the Absolute I does not create the not-I as the strong idealist reading holds. In other words, according to this interpretation the mind is sheer activity and it is spontaneous, that is, one cannot switch off the activity and spontaneity of one's mind. This activity and spontaneity gives rise to one's particular self, that is, through this activity and spontaneity one comes to realise that one is always thinking. But in order for one to gain knowledge and achieve self-consciousness one needs contact with a not-I, with 
reality, so that the subject-object relation is established and the proper conditions for knowledge and self-consciousness is well-grounded.

This is a very insightful point, which is easily explained by the following: If one were not to meet with a not-I, if one were to be put into some sort of cocoon and deprived from any and all sense-perception then one would be just an active particular mind without the ability of gaining knowledge and of being self-conscious. Thus according to this reading, Fichte does not have any ontological claim about the world, as the strong idealist holds, Fichte is not saying that the Absolute I actually creates the individual I and the not-I; rather, Fichte's Absolute I has only an epistemological function, that is, it provides the proper foundations for the individual I (i.e. the self-conscious I that accompanies all representations) to establish the subject-object relation with reality and attain knowledge. Zöller (1998:36) corroborates:

The I is here portrayed as self-enclosed to the point of seeming totally self-sufficient and a world unto its own. Yet the self-sufficiency in question is not the ontological independence or self-sufficiency of a divine mind, but the epistemological isolation of a finite intelligence that originally knows only itself, including its own states, and that derives all other knowledge from the experience of its own finitude. Viewed that way, Fichte's account of experience is an effort to derive the consciousness of external objects from the limitations that the I encounters in its original, intellectual intuition [my italics].

Note that the problem of solipsism does not arise here, as noted by Kolias (2000:131, that is, when the individual I finds its limits, when it encounters the not-individual-I, when it encounters reality, it becomes aware that it is not a sole entity as it encounters other human beings, i.e. entities that appear to behave in a rational manner, and things, i.e. entities that appear not to behave in a rational manner, in reality. Also note here that the problem of bridging the gap between the subject and the object does not arise. For Fichte this is not a problem since the mind is always active and spontaneous and as such it is always encountering reality. This encountering is dependent on what Fichte calls the Anstoss, the check, the limitation, the challenge that reality impinges on the activity of the individual I. When the individual I encounters reality, the individual I perceives reality as an obstacle, it perceives reality impinging on its activities. And I quote Fichte defining the Anstoss as:

The Anstoss (which is not posited by the positing I) occurs to the I insofar as it is active, and is thus an Anstoss only insofar as the I is active. Its possibility is conditioned by the activity of the I: no activity of the I, no Anstoss. And vice versa: the I's activity of determining itself would, in turn, be conditioned by the Anstoss: no Anstoss, no self-determination. Moreover, no self-determination, nothing objective....(Fichte 1970: 212)

The activity of the individual I over reality, and reality's impinging on the individual I is what establishes the subject-object relation that gives rise to knowledge. I quote Breazeale (1993:99):

The task of somehow bridging the gap between the conscious self and the objective world is simply not a problem that can arise within the context of the Wissenschaftslehre, which considers the synthetic link between self and world, freedom and Anstoss, to be a fundamental condition for the very possibility of self-consciousness. 
I note that Fichte's position on this issue, I mean the way he bridges the gap between subject and object, is very similar to Spinoza's. Lloyd (1994:28-30) notes that Spinoza holds:

Bodies are more or less powerful according to their capacity to sustain and benefit from a variety of activities without surrendering their own distinctive ratios of motion and rest. The superiority of the human body over others resides in the fact that it is "affected in a great many ways by external bodies, and is disposed to affect external bodies in a great many ways" (II P14 Dem). This makes it possible for the body to maintain its individuality throughout a wide variety of change...Human life...is a struggle between activity and passivity, autonomy and dependence, freedom and bondage.

For Spinoza, the individual, the mind and body that forms an individual is always active and it is always interacting with the environment that it is inserted in. This interaction is what yields knowledge, all three kinds of knowledge, viz. opinion (which is mainly achieved through sense perception), reason (which is mainly achieved through the use of a rational deduction) and intuition (which is a rational 'insight' that occurs when one connects the parts to the whole). Without the interaction, without the encounter with reality, there could not be knowledge. The passage quoted describing Spinoza's position could have easily been mistaken for a passage describing Fichte's position. Therefore, both Spinoza and Fichte understand that knowledge can only be produced through the interaction of an individual's mind with reality. This fact places them apart from the usual pre-Kantian understanding that knowledge of reality can be gained through concepts alone (i.e. the rationalist conception) or through sense-perceptions alone (i.e. the empiricist conception). Certainly, Kant had realised that both the rationalist and empiricist conception are not opposing, but complementary positions; Kant, however, failed to devise a unified system as Spinoza had done before him, and as Fichte did after him.

This modern reading also fits well with the wider picture of the time (just as the classic and strong idealist do). It fits well with the fact that Kant was trying to solve the enlightenment crisis and that the First Critique was trying to lay down the foundations of knowledge, and it understands that Fichte was doing the same in the Wissenschaftslehre project. However, Fichte lays down the foundations of knowledge in a unified system, a system unified in the Absolute I, which is in direct contrast with Kant's dualistic system. It could be argued that Fichte offers us a monistic philosophy, just as Spinoza did. But by monistic here it is not meant a system based on one substance; rather, by monistic it is meant here that there is an absolute principle, the Absolute I, which is sheer activity and spontaneity, and which is the basis for all rationality. Pippin (2000:164) corroborates this when he says that 'if there is a 'monism' emerging in the post-Kantian philosophical world, the kind proposed by Fichte...is what might be called a normative monism, a claim for the "absolute" or unconditioned status of the space of reasons'.

\section{Final Thoughts}

Following from what I have discussed thus far, I wish to propose that the classical reading of Schelling and Hegel and the modern reading of Breazeale, Pippin, Zöller and Henrich could be seen as complementary readings. That is, these readings capture different aspects of the Fichtean system: the classical reading focus on the relation be- 
tween finite entities with the infinite/Absolute, and the modern reading focuses on the relation between finite entities with other finite entities. This fact becomes very apparent if one reads Fichte as a Spinozist. In Spinoza we also find those two kinds of intercourse, the relation between the finite with the infinite and between the finite with other finite things. Gatens and Lloyd (1999:47) have noted this aspect of Spinoza's philosophy. I quote:

We have, on the one hand, the relation of dependence which binds each individual necessarily to Substance as one of its modes; and, on the other, the causality of external forces which binds the individual to other finite modes. But the two kind of dependence interlock. It is only through the meditating force of other finite modes which impinge on it that the individual has access to the sustaining power of Substance. It is only as a finite individual among other finite individuals - made vulnerable but also sustained by their collective power - that the individual exists. The shift between the two stories enacts Spinoza's treatment of the interconnections between contingency and necessity bondage and freedom.

Hence, if Fichte is read as a Spinozist, it is possible to make sense of both the classical and modern readings as complementary. In the classical reading, the Absolute I is indeed God who acts as the guarantor that the subjective can successfully enact in/with the objective. But this reading is just half of the picture. The question how a subjective entity is able to attain knowledge of objective reality has still to be answered satisfactorily. This question is answered convincingly by the modern reading. The Absolute I in this reading is sheer rational and spontaneous activity, an activity that gives rise, that is the foundation of individual "I"s. Through this sheer activity individual "I"s are able to realise that they are always thinking, they become self-aware, and as such they become aware that there are limits to their self-awareness. They realise that they are able to interact with certain entities, i.e. other individual "I"s and objects, other than themselves and as such they are able to establish a connection with these entities. This connection is what enables them to attain knowledge of reality. Support for my proposal here can be found in the fact that both readings are supported by different writings and passages within the Wissenschaftslehre project. The canon of the project encompasses some 17 writings or versions of these writings and as such it is possible to conceive that Fichte sometimes referred to the concept of the Absolute I as God and other times to the Absolute I as sheer rational and spontaneous activity.

The last point I wish to make in this paper concerns all three interpretations of the concept of the Absolute I. Generally speaking, commentators in philosophy encyclopaedias or/and introductory texts on Fichte, Schelling and Hegel understand these philosophers as being absolute idealists. These introductory commentaries and texts understand and portray Fichte, Schelling and Hegel as holding both i. the view that empirical objects do not exist independently of the human mind, and as such Fichte, Schelling and Hegel reject transcendental realism - rather, for Fichte, Schelling and Hegel hold the view that these objects are 'appearances' and therefore dependent, in some sense, on the human mind, and as such they are considered idealists; and ii. these objects are not merely 'appearances' for us, human being, but are also 'appearances' for an absolute mind (e.g. Hegel's Geist, which is probably the most famous example here). This common reading of Fichte, Schelling and Hegel understands that these philosophers are not transcendental or subjective idealists, as Kant, but absolute 
idealists. If we refer back to those three interpretations of the concept of the Absolute I we may reach a different understanding however. The classical interpretation falls well within this common understanding of Fichte being an absolute idealist as the Absolute I is God, who creates the whole of reality, relative "I"s and nature as a not-I. The strong-idealist and the modern interpretation (i.e. those interpretations in which the absolute I is the rationality and spontaneity of the human mind), however, do not fall within this common understanding of Fichte as an absolute idealist. According to these interpretations, I understand, Fichte should be read as a transcendental or subjective idealist, just as Kant. In fact Beiser (2002:355) does overtly interpret Fichte as a transcendental or subjective idealist, thus rejecting the view that Fichte was an absolute idealist; and Henrich, who defends the modern reading, puts forward the view that when Fichte says that the concept of the self is a manifestation of God Fichte is trying to make the concept of the self intelligible through the concept of God, that is, both concepts are self-creating, are causa sui, and thus not dependent on anything else. I quote:

Fichte...was convinced that his theory can yield insight into the ground of the Self; according to him, the Self is a manifestation of God. It looks as though Fichte is now furnishing a cause for freedom in just the way Kant viewed it and which cannot really be brought into harmony with Fichte's basic insight. Yet he was not suffering a mental lapse when he offered this explanation. Fichte wants to make the essence of the Self precise and intelligible with the help of the concept of God. This takes place as follows: Self-consciousness is an intimate unity arising from an inconceivable ground which the Self does not control. At the same time, the Self makes itself manifest to itself. It possesses itself as Self, and must acquire additional knowledge of itself in the course of performing its characteristic activity. (Henrich 2003:42)

Henrich's explanation is very persuasive, and Beiser (2003:284-288) makes this same point. However, I find it extremely puzzling that Schelling and Hegel understood the Absolute I as God, and thus not to be read as an analogy of the concept of God. I ask the question here: How could Schelling and Hegel have got Fichte's system so wrong given that they were peers and communicate often? Nevertheless, if further support for the strong-idealist or modern interpretation is gathered, then, perhaps, the common understanding of Fichte as an absolute idealist must be relinquished, and Fichte should then be placed side by side with Kant as a transcendental or subjective idealist, leaving Schelling and Hegel as the sole absolute idealists of post-Kantian German philosophy. The debate here will be fought over by those who defend a metaphysical reading of Fichte and who understand that Fichte (and the other absolute Idealists) have disregarded Kant's advice that we should not engage with concepts of which we can have no experience (instances of this are Fichte's Absolute I, Schelling's Absolute, and Hegel's Geist), and those who defend a non-metaphysical reading of Fichte and who interpret his philosophy as having some powerful insights into some of the problems which are still troublesome for contemporary philosophy (an instance of this is the modern reading of Fichte's Absolute I which deals with epistemological issues and which could be seen as an attempt to re-establish foundationalism). 


\section{References}

Agnotes, K., and Moven, F. 2001. "Rotter eller ironi: Batalje i var romantiske skje. Om Schegel, Kinck and postmodernism", in Vir har altid voert romantiske. En bok om det modern, Bergen: Ariadne Forlag AS.

Bayle, P. 1826. An Historical and Critical Dictionary, London: Hunt and Clarke.

Bayle, P. 1697. Dictionnaire Historique et Critique, Rotterdam: Leers.

Beiser, F.C. 2002. German Idealism - The Struggle Against Subjectivism 1781-1801, Cambridge, MA, and London: Harvard University Press.

Bowie, A. 1993. Schelling and Modern European Philosophy: An Introduction, London: Routledge.

Bowie, A. 2003. Introduction to German Idealism: From Kant to Habermas, Cambridge: Polity Press.

Bowman, C. 2002. "Fichte, Jacobi and the Atheism Controversy", in New Essays on Fichte's Later Jena Wissenschaftslehre, ed. Daniel Breazeale and T. Rockmore, Evanston, Illinois: Northwest University Press.

Breazeale, D. 1993. "Introduction", in Fichte: Early Philosophical Writings, Ithaca: London, Cornell University Press.

Copleston, F.C. 1946. "Pantheism in Spinoza and the German Idealists", in Philosophy - The Journal of the British Institute of Philosophy, Vol XXI.

Curley, E. 1969. Spinoza's Metaphysics, Cambridge, MA: Harvard University Press.

Di Giovanni, G. 1994. "Introduction", in The Main Philosophical Writings and the Novel Anvill, by Jacobi, F.H., Montreal \& Kingston, London and Buffalo: McGill-Queens University Press.

Dusing, K. 1999. "Kant's Doctrine of Postulates in Schelling and Hegel", in The Emergence of German Idealism, ed. Michael Bauer and Daniel Dahlstrom, Washington, DC: The Catholic University of America Press.

Fichte, J.G. 1970. Science of Knowledge: Wissenschaftslehre - with First and Second Introductions, ed. and trans. by Peter Heath and John Lachs, New York: Century Philosophy Source Books.

Fichte, J.G. 1993. "Selected Correspondence" in Fichte: Early Philosophical Writings, trans. and ed. Daniel Breazeale, Ithaca and London: Cornell University Press.

Gatens, M., and Lloyd, G. 1999. Collective Imagings: Spinoza, Past and Present, London and New York: Routledge.

Green, G. 1978. "Introduction", in Attempt at a Critique of All Revelation, by J.G. Fichte, Cambridge: Cambridge University Press.

Hegel, G.W.F. 1977. The Difference Between Fichte's and Schelling's System of Philosophy, translation by HS Harris and Walter Cerf, Albany: State University of New York Press.

Henrich, D. 1982. "Fichte's Original Insight", in Contemporary German Philosophy Vol. 1, ed. D.E. Christensen, University Park and London: The Pennsylvania State University Press. 
Henrich, D. 2003. Between Kant and Hegel: Lectures on German Idealism, ed. David S. Pacini, Cambridge, Massachussets, and London: Harvard University Press.

Jacobi, F.H. 1994. "Concerning the Doctrine of Spinoza in Letters to Moses Mendelssohn", in The Main Philosophical Writings and the Novel Allwill, trans. and ed. by George Di Giovanni, Montreal \& Kingston, London and Buffalo, McGill-Queen's University Press.

Kolias, H. 2000. "Positing/Hovering: The Early Romantic Reading of Fichte", Pli, Vol 10.

Lloyd, G. 1994. Part of Nature: Self Knowledge in Spinoza's Ethics, Ithaca and London: Cornell University Pres.

Millan-Zabert, E. 2000. "Romantic Rationality", Pli, Vol. 10.

Neuhouser, F. 1990. Fichte's Theory of Subjectivity, Cambridge: Cambridge University Press.

Novalis 2003. Fichte Studies, ed. Jane Kneller, Cambridge: Cambridge University Press.

Pippin, R. 2000. "Fichte's Alleged Subjective, Psychological, One-Sided Idealism”, in The Reception of Kant's Critical Philosophy, ed. Sally Sedgwick, Cambridge: Cambridge University Press.

Schelling, F.J.W. 1980. The Unconditional in Human Knowledge, "On the I as a Principle of Philosophy", translation and commentary by Fritz Marti, Lewisburg: Bucknell University Press.

Wright, W. 2003. "The Shadow of Spinoza in Fichte's WL 1804", Idealistic Studies, Vol. 33, Issues 2-3.

Wolfson, H.A. 1948. The Philosophy of Spinoza, Cambridge, MA: Harvard University Press.

Zöller, G. 1998. Fichte's Transcendental Philosophy: The Original Duplicity of Intelligence and Will, Cambridge: Cambridge University Press. 